\title{
Building capacity between the private emergency food system and the local food movement: Working toward food justice and sovereignty in the global North
}

\author{
Jesse C. McEntee ${ }^{a}$ \\ Food Systems Research Institute and Tufts Initiative for the Forecasting and Modeling of Infectious Diseases \\ Elena N. Naumova ${ }^{\mathrm{b}}$ \\ Department of Civil and Environmental Engineering, Tufts University, and Tufts Initiative for \\ the Forecasting and Modeling of Infectious Diseases
}

\begin{abstract}
Submitted 2 May 2012 / Revised 28 June and 26 July 2012 / Accepted 27 July 2012 / Published online 4 December 2012
Citation: McEntee, J. C., \& Naumova, E. N. (2012). Building capacity between the private emergency food system and the local food movement: Working toward food justice and sovereignty in the global North. Journal of Agriculture, Food Systems, and Community Development, 3(1), 235-253. http://dx.doi.org/10.5304/jafscd.2012.031.012

Copyright (C) 2012 by New Leaf Associates, Inc.
\end{abstract}

\begin{abstract}
One area of food system research that remains overlooked in terms of making urban-rural distinctions explicit is the private emergency food

a Corresponding author: Jesse C. McEntee, PhD, Managing Partner, Food Systems Research Institute LLC; P.O. Box 1141; Shelburne, Vermont 05482 USA; +1-802-448-2403; www.foodsystemsresearchinstitute.com; imcentee@foodsri.com

b Elena N. Naumova, PhD, Associate Dean for Research, School of Engineering; Professor, Department of Civil and Environmental Engineering, Tufts University; also Tufts Initiative for the Forecasting and Modeling of Infectious Diseases (InForMID) (http://informid.tufts.edu/); elena.naumova@tufts.edu

Acknowledgments: The authors are grateful to the Economic and Social Research Council's Centre for Business Relationships, Accountability, Sustainability and Society at Cardiff University as well as the Center for Rural Partnerships at Plymouth State University for financial support during this research. The authors are also grateful to the three anonymous reviewers who provided constructive feedback on earlier drafts of this article.
\end{abstract}

system of food banks, food pantries, soup kitchens, and emergency shelters that exists throughout the United States. This system is an important one for millions of food-insecure individuals and today serves nearly as many individuals as public food assistance. In this article, we present an exploratory case that presents findings from research looking at the private emergency food system of a rural county in northern New England, U.S. Specifically, we examine the history of this national network to contextualize our findings and then discuss possibilities for collaboration between this private system and the local food movement (on behalf of both the public and the state). These collaborations present an opportunity in the short term to improve access to high quality local foods for insecure populations, and in the long term to challenge the systemic income and race-based inequalities that increasingly define the modern food system and are the result of prioritizing market-based reforms that re-create inequality at the local and regional levels. We propose 
alternatives to these approaches that emphasize the ability to ensure adequate food access for vulnerable populations, as well as the right to define, structure, and control how food is produced beyond food consumerism (i.e., voting with our dollars), but through efforts increasingly aligned with a food sovereignty agenda.

\section{Keywords}

emergency food, food justice, food sovereignty, rural and urban

\section{Introduction}

The rural private emergency food system is an overlooked area of research. The popularity of local food has increased in urban and rural areas alike, yet despite the social and economic capital driving this innovative food movement, foodinsecure populations remain ignored to a large degree. We know that the rural food environment is substantively different than the urban food environment (Sharkey, 2009). People in rural areas generally have less money to spend on food and they live further from markets where local food producers sell their products (Morton \& Blanchard, 2007). Producers are predominantly located in rural areas where land and water resources are abundant, yet the most profitable markets for their products more often than not are located in urban centers where they can more easily access a concentrated population center with greater financial capital. These urban-rural distinctions can be made about multiple aspects of food systems research. For instance, early applications of the food desert concept (and the corresponding efforts to identify them) were overwhelmingly situated in urban places. Today, there is recognition that there is not a single food desert definition that can be universally applied. Researchers as well as government authorities have recognized this; for instance, the United States Department of Agriculture (USDA) has adopted different criteria for urban and rural food deserts. In examinations of local food, some have identified key urban-rural distinctions. For example, McEntee's (2010) contemporary and traditional conceptualization has been used to distinguish between a broad base of activities that are local in terms of geographical scale, but potentially exclusive in terms of their social identity and obstacles to adequate access. Access in this sense is not represented by a Cartesian notion of physical proximity, however; it is also indicative of access barriers in terms of financial ability as well as structural and historical (e.g., institutional racism) processes that privilege some, but harm others (McEntee 2011a). ${ }^{1}$ These concerns are increasingly recognized as part of growing food justice and food sovereignty agendas.

The private emergency food system (PEFS) is a national network of food banks, food pantries, soup kitchens, and shelters that operate largely to redistribute food donated by individuals, businesses, and the state. This is a tremendously important system that serves both urban and rural food-insecure populations. Based on a review of this system's functionality, urban-based critiques of this system, and findings from an exploratory qualitative study, we propose that there are key distinctions between the urban and rural PEFSs that have been overlooked (in the same manner that urban and rural local food systems are conflated). The PEFS serves as a safety net for many, yet it struggles financially and lacks access to the high-quality foods (e.g., fresh produce and meat) that clients of this system often prefer. In this article we present emergent opportunities to develop the collaborative capacity between the PEFS and the rural local food system in ways that address the needs of the PEFS and utilize the assets of the burgeoning local food movement. Furthermore, we explain how these synergies potentially contribute to food justice by providing high-quality food to low-income populations. We begin the article with a review of pertinent literatures. This is followed by a depiction of the PEFS, summary of existent critiques, and presentation of our data. We propose that livelihood strategies related to traditional localism (McEntee, 2010) contribute to food justice and food sovereignty

\footnotetext{
${ }^{1}$ Cartesian understandings of space utilize a grid-based measurement of physical proximity. These types of proximitybased understandings of food access (i.e., food access is primarily a matter of bringing people physically closer to food retailers, as is promoted by the USDA Food Desert Locator) tend to overlook other nuanced forms of food access based on knowledge, culture, race, and class.
} 
agendas by focusing on the natural and social assets of rural communities. We conclude with a discussion of the possibilities for not only remediating the PEFS, but challenging the corporate food regime that currently institutionalizes it.

\section{Local Foods, Food Justice, and Food Sovereignty}

Consumer confidence in the conventional food sector has decreased as a result of food scares (Morgan, Marsden, \& Murdoch, 2006), with consumers feeling alienated from modern-day food production (Sims, 2009). From these consumerbased concerns over food safety and a general alienation from modern-day food production, alternative food initiatives and movements have surfaced (including local food initiatives). Feenstra (1997) made the case for local foods as an economically viable alternative to the global industrial system by providing specific steps to be taken by citizens to facilitate the transition between the local and the global; it is these forces that have become the focus of food provisioning studies (Winter, 2003). These efforts include more sustainable farming methods, fair trade, and food and farming education, among others; these have been reviewed extensively elsewhere, such as by Kloppenburg, Lezberg, De Master, Stevenson, and Hendrickson (2000) and Allen, FitzSimmons, Goodman, and Warner (2003). Essentially, all are categorized by a desire to create socially just, economically viable, and environmentally sustainable food systems (Allen et al., 2003) and the majority are now collectively referred to as the dominant food movement narrative (Alkon \& Agyeman, 2011). It is from this narrative that the local food movement emerges.

Food justice efforts have successfully utilized food localization efforts to improve food access opportunities for low-income and minority communities. These efforts typically occur in urban areas and target low-income minority populations (Alkon \& Norgaard, 2009; Gottlieb and Joshi 2010; Wekerle, 2004; Welsh \& MacRae, 1998). The concept of food justice supports the notion that people should not be viewed as consumers, but as citizens (Levkoe, 2006); by linking low-income and minority populations with alternative modes of food production and consumption, advocates prioritize human well-being above profit and alongside democratic and social justice values (Welsh \& MacRae, 1998).

This represents "more than a name change" departure from conventional food security concerns; it is rather a systemic transformation that alters people's involvement in food production and consumption (Wekerle, 2004, p. 379). Increasingly substantiated by racial and income-based exclusion, food justice operates to prioritize just production, distribution, and access to food within the communities being impacted. This is the focus of the food justice movement, though environmental and economic benefits often result from these efforts as well. A recently published volume edited by Alkon and Agyeman (2011) unpacks various forms of food justice, ranging from issues of production (e.g., farmworker rights) to distribution, consumption, and access. In this article we are concerned with the consumption element of the food chain; food justice efforts in this realm often take the form of alternative food initiatives that create new market-based or charity-based solutions to inadequate food access (e.g., farm-to-school programming that link schools and local farmers, slidingscale payment plans for low-income consumers at farmers' markets that are subsidized by wealthier patrons, or agricultural gleaning programs) that stress social equity and solutions that are implemented by and for the people impacted by inadequate access to food. This latter element is a definitive characteristic of food justice initiatives. Most recently, Alkon and Mares (2012) situated food justice in relation to food sovereignty, finding that although food justice and community food security frameworks often challenge conventional agricultural and food marketing systems, the food sovereignty framework is the only one to explicitly underscore "direct opposition to the corporate food regime" (p. 348). This is because both contemporary food justice and (community) food security frameworks often operate within traditional markets that are agents of the industrial agricultural system representative of a neoliberal political economy. This marks a departure between food justice and food sovereignty; La Via Campe- 
sina, a major proponent of food sovereignty, defines the concept as:

the right of peoples to healthy and culturally appropriate food produced through sustainable methods and their right to define their own food and agriculture systems. It develops a model of small scale sustainable production benefiting communities and their environment. It puts the aspirations, needs and livelihoods of those who produce, distribute and consume food at the heart of food systems and policies rather than the demands of markets and corporations. (La Via Campesina, 2011, para. 2)

Whereas food justice often works to create solutions in sync with market structures by filling the gaps in government services, food sovereignty focuses on dismantling the corporate food regime.

\section{History and Structure of the PEFS}

An area of the food system where food justice advocates have increasingly engaged in an urban setting is the PEFS. Operating on a charity basis, emergency food assistance provides food to individuals whose earnings, assets, and social insurance options have not met their needs (Wu \& Eamon, 2007). Public government-run assistance programs include welfare, the Supplemental Nutrition Assistance Program (SNAP), Medicaid, and subsidized housing. Private emergency food assistance is provided by nonprofit organizations and includes soup kitchens, food pantries, food banks, food rescue operations (Poppendieck, 1998), and "emergency shelters serving short-term residents" (emphasis added) (Feeding America, 2010a, p. 1).

Largely in reaction to dissatisfaction with the federal food stamp program, Congress passed the Omnibus Budget Reconciliation Act in 1982. This act allowed federally owned surplus commodity food to be distributed by the government for free to needy populations. Prior to its passage, the vast majority of food assistance in the U.S. was governmentally provided through the food stamp program (now the Supplemental Nutrition Assistance Program [SNAP]) and the majority of food that food pantries received came from individuals and businesses. The act's success was followed by the Temporary Emergency Food Assistance Act (TEFAP) in 1983, which began the process of routinely distributing excess commodities through private emergency food programs, such as food banks and food pantries (Daponte \& Bade, 2006). Food pantries flourished as a result of commoditysourcing, since they now began receiving a reliable stream of food. Businesses that previously did not want to be involved in emergency food provisioning activities could now dispose of unwanted inventory for a much cheaper rate by giving it away (Daponte \& Bade, 2006) (see figure 1). In fiscal year 2009, Congress appropriated USD299.5 million for the program, made up of USD250 million for food purchases and USD49.5 million for administrative support (USDA FNS, 2010).

In the U.S., companies defined as $C$ corporations by tax code (the majority of U.S. companies) can collect an enhanced tax deduction for donating surplus property, including food. Thus when food businesses donate food to a charity, including food banks and pantries, the businesses can take a deduction equal to 50 percent of the donated food's appreciated value. In addition, the Bill Emerson Good Samaritan Food Donation Act of 1996 provides safeguards for entities donating food and groceries to charitable organizations by minimizing the risk of legal action against donors. Companies are not required to publicly disclose deductions for food donations, though in 2001 corporations wrote off USD10.7 billion in deductions (Alexander, 2003). Feeding America received USD663,603,071 in charitable donations in 2006. In a 2003 Chicago Tribune article, Delroy Alexander described how America's Second Harvest received USD450 million in donated provisions in 2001, USD210 million of which came from just 10 major food companies, such as Kraft, Coca-Cola, General Mills, ConAgra Foods, Pfizer, and Tropicana (Alexander, 2003). The top five donors each gave more than USD20 million in food, with the top contributor at USD38 million. Current figures are unavailable, though many companies proudly display pounds of food donated on their websites. For instance, Walmart's website states: 
From November 2008 to November 2009, the Walmart stores and Sam's Club locations have already donated more than 90 million pounds $[41,000,000 \mathrm{~kg}]$ of food.... By giving nutritious produce, meat, and other groceries, we've become Feeding America's largest food donor. (Walmart, 2010)

This arrangement allows for unwanted food (food that would otherwise be considered waste) to be utilized; it acts as a vent for unwanted food, allowing large corporate entities to dump surplus product of questionable nutritional quality upon the PEFS. Simultaneously, these corporations are receiving tax breaks and benefiting from policies that minimize their legal risk. Approximately 80 percent of food banks belong to Feeding America, a member organization that acts as an advocate and mediator in soliciting food from major food companies and bulk emergency food providers.
This network has 205 food bank members that distribute food and grocery products to charitable organizations. Nationwide, more than 37 million people accessed Feeding America's private food assistance network in 2009 (up 46 percent from 2005), while 127,200 accessed it in New Hampshire (Feeding America, 2010b).

\section{Critiques of the PEFS}

Critical assessments of the PEFS range from those focused on political-economic relations to on-theground implementation of this redistributive system. In the following section we have grouped these appraisals into four main points. First, the PEFS is largely "emergency" in name only. Second, distribution of food in the PEFS is largely unregulated. Third, nutritional content of donated items is frequently overlooked for the sake of its quantity. Fourth, because of their limited budget and foodstorage capacity, the PEFS requests nonperishable,

Figure 1. United States Emergency Food Network (adapted from Feeding America, 2010a)

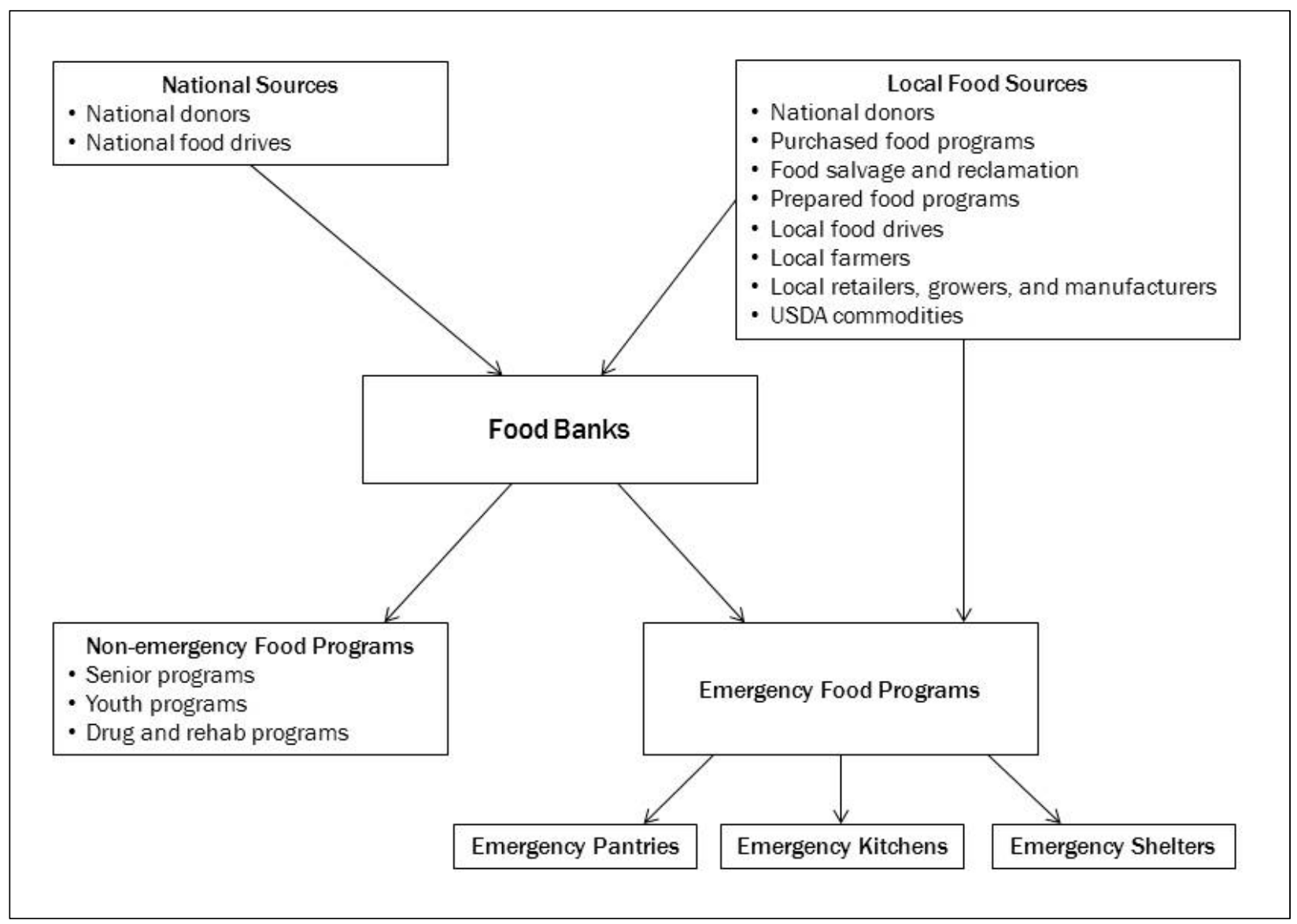


and resultantly, low-nutrition donations. Related to this point, perpetuation of the PEFS as it currently operates supports a short-term food strategy that supports immediate caloric need while sacrificing long-term health (and ignoring its associated costs).

A prominent critique of the PEFS is that it is "emergency" in name only, and examples highlight the emergency programmatic emphasis of programs even though their services appear to be operating in a nonemergency manner. The U.S. government describes TEFAP as a program that "helps supplement the diets of low-income needy persons... by providing them with emergency food" (USDA FNS, 2010). Feeding America, "the nation's largest organization of emergency food providers," describes food pantries as "distributing food on a short-term or emergency basis" (the NHFB shares this definition) (Feeding America, 2010a, p. 13). According to Feeding America's Hunger in America 2010 report, approximately 79.2 percent of clients interviewed reported that they had used a pantry in the past year, indicating that they were not new clients. Multiple researchers have observed that many food pantries are being used on a regular, long-term basis (Beggs, 2006; Bhattarai, Duffy, \& Raymond, 2005; Daponte, Lewis, Sanders, \& Taylor, 1998; Hilton, 1993; Molnar, Duffy, Claxton, \& Conner, 2001; Mosley \& Tiehen, 2004; Tarasuk \& Eakin, 2005; Warshawsky, 2010).

Along these lines, others have cited how the PEFS is unregulated to its detriment; for instance, many private donations do not have any federal or state laws regulating their distribution (Bhattarai et al., 2005). The unregulated nature of any charity brings both benefits and burdens, and one benefit to the PEFS has been the ability to utilize the efforts of a large volunteer base. However, it has been proposed that pantries that operate with a largely volunteer workforce employ subjective eligibility criteria and a "they should be satisfied with whatever they get" mindset on behalf of workers (volunteers as well as paid staff) (Tarasuk \& Eakin, 2005, p. 182). Food pantry clients may have limited rights and entitlement to the food being distributed, "further reinforcing that people are unable to provide for themselves" (Molnar et al., 2001, p. 189) in this redistributive system. In fact, it has been shown that workers "routinely eschew the aesthetic values that dominate our retail system" where "distribution of visibly substandard or otherwise undesirable products is achieved because clients have few if any rights" and "are in desperate need of food" (Tarasuk \& Eakin, 2005, p. 184).

The belief of some workers that clients should be satisfied with whatever items they receive underlies the non-nutritional focus threaded throughout the private emergency food system. This is especially evident from the supply side. Government commodities serve as a major source of food for the PEFS. Commodity foods are provided to food banks, directly to independent agencies, and to Feeding America (Feeding America, 2012c). The original intents of this commodity program were to distribute surplus agricultural commodities and reduce federal food inventories and storage costs, while simultaneously helping food-insecure populations. In 1988, however, much of the federal government's surplus had been exhausted, and as a result the Hunger Prevention Act of 1988 appropriated funds for the purchase of commodities for TEFAP (USDA FNS, 2010).

The PEFS's other major contributor, private corporations, do not explicitly concentrate on the nutritional content of their donations. Corporations benefit from considerable tax incentives along with liability protection; they can donate food that would otherwise be wasted, forgoing dumping costs while engaging in what many of these entities now call "corporate social responsibility." For instance, pounds of donated food are showcased and used as progress markers to show how successfully hunger is being combated. Feeding America states that it distributes 3 billion pounds (1.4 billion kg) of food every year (Feeding America, 2012a). Clicking on a few of Feeding America's "Leadership Partners" on its homepage website (Feeding America, 2012b) yields similar language. For instance, ConAgra states that, "In the last dozen years, ConAgra Foods has provided more than 166 million pounds of food to families in need" (ConAgra, 2009, para. 5), Food Lion (part of the Delhaize Group) has "donated more than 21 million pounds of food" (Food Lion, 2010), and 
“just last year, Procter \& Gamble contributed nearly 30 million pounds of product" (Procter \& Gamble, 2010). These figures provide no indication of nutritional content, although one pound of naturally flavored drink boxes has different nutritional composition than one pound of fresh produce. If success is measured in terms of quantity, then this will be the criterion that drives emergency food provisioning.

Charities are easy targets for critique; they often operate on a shoestring, use labor with different levels of knowledge and experience, and much of the time are put in a financially and socially powerless position, at the whims of donors. One result is that nonperishable or lowperishability items are preferred (Tiehen, 2002; Verpy, Smith, \& Reicks, 2003); these last longer and do not require refrigeration. Their long shelf life means handling and transport is not timesensitive. These products cost less and are more likely to be donated. Nutrient-poor foods are less healthy overall (Monsivais \& Drewnowski, 2007); previous food pantry investigations discovered the poor nutrient composition of donated items, especially in regards to adequate levels of calcium, vitamin $\mathrm{A}$, and vitamin $\mathrm{C}$ (Akobundu, Cohen, Laus, Schulte, \& Soussloff, 2004; Irwin, Ng, Rush, Nguyen \& He, 2007). Donating large amounts is important since donation quantity is prioritized by agency recipients. Rock, McIntyre, and Rondeau (2009) found a misalignment between donor intent and client preference indicative of the "ignorance among food-secure people of what it is like to be food-insecure" (p. 167). Food banks and food pantries are pressured to accept foods on unfair grounds, just as clients are pressured to accept whatever food is handed to them. In at least one other case, food pantry donors "did not consciously consider nutrition when deciding which foods to donate" (Verpy et al., 2003, p.12).

A demand-side perspective of private emergency food provisioning reveals somewhat complementary conditions that support the acquisition and distribution of low-quality foods. The longterm health consequences associated with the consumption of low-quality foods can be overlooked to satisfy immediate food needs, thereby reinforcing the value placed on the low-quality supply being donated. While expenses like shelter, heat, and medical expenses are relatively inelastic, food is flexible and can be adjusted based on these demands. On a limited budget, it is often the case that whatever money is left over is used for food (Furst, Connors, \& Bisogni, 1996; McEntee, 2010). As reported by McEntee, a homeless shelter resident commented:

It's likes this, your oil's almost out, your electricity's high and they're going to shut it off, what are going to do? Well, we're going to have to cut down on our food budget. Do what you gotta do... you can buy your family packs and suck it up and eat ramen noodles. (McEntee, 2010, p. 795)

Sometimes these types of food are chosen out of necessity (that is the only type of food offered) and other times it is out of habit (they are used to eating it). ${ }^{2}$ With the recent recession in the U.S. economy, purchases of cheap, ready-to-eat processed foods have increased. An Associated Press article entitled, "ConAgra Foods 3Q profit rises, maintains outlook" (Associated Press, 2010, para. 1) states:
Strong sales of low-priced meals such as Banquet and Chef Boyardee and lower costs pushed ConAgra Foods Inc.'s third-quarter profit up 19 percent. Cheap prepared foods like those that ConAgra offers have appealed to customers during the recession as they look for ways to save money and eat at home more.

\section{Methods and Research Setting}

Approximately 7.7 percent of New Hampshire's population is food-insecure (Nord, Andrews \& Carlson, 2008); 8 percent of the state's population lives in poverty, while 9.4 percent of Grafton County's population lives in poverty (U.S. Census Bureau, 2008). Grafton County was selected as the

\footnotetext{
2 The amount of processed food, especially in the form of prepared meals and meals eaten outside the home, is steadily increasing in the United States (Stewart, Blisard, \& Jolliffe, 2006).
} 
research site based on proximity to researchers as well as the existence of food insecurity. Grafton County (figure 2) has a population of 81,743 and a population density of 47.7 people per square mile (18.4 people per square kilometer) (U.S. Census Bureau, 2008).

Unlike the other two primarily rural northern counties of New Hampshire (Carroll and Coos counties), Grafton County contains two universities that serve as educational and cultural centers (Dartmouth University in Hanover and Plymouth State University in Plymouth).

Accordingly these areas attract residents with above-average educational attainment and income, thus offering a variegated set of social and economic conditions which are differentiated from the rest of the county. There are 14 registered food pantries in Grafton County (of a total of 165 in New Hampshire) (New Hampshire Food Bank, 2010). In 2012, there were 92 SNAP-authorized stores within the county, marking a 13 percent increase from 2008 (USDA FNS, 2012a). Approximately 16 percent of students were free lunch eligible in 2008 (USDA FNS, 2012b). In terms of local food potential, there were 10 farmers' markets in 2010 (USDA AMS, 2012) with 3.3 percent of farm sales attributable to direct to consumer sales ; U.S. Census of Agriculture, 2012).

A purposive sampling method (Light, Singer, \& Willett, 1990) was used to identify respondents $(\mathrm{N}=16)$ who work regularly in Grafton County's PEFS. This included state employees, although the majority were workers and volunteers at food banks, soup kitchens, food pantries, and homeless shelters. These respondents were selected based on their above-average knowledge about hunger, food insecurity, and private emergency food provisioning in Grafton County (beyond their personal experience). Although some questions were specific to the respondent's area of expertise, the same general open-ended question template was used to facilitate informative discussion on topics related to food access, such as affordability, nutrition, and food provisioning (see table 1).
Figure 2. Grafton County, New Hampshire

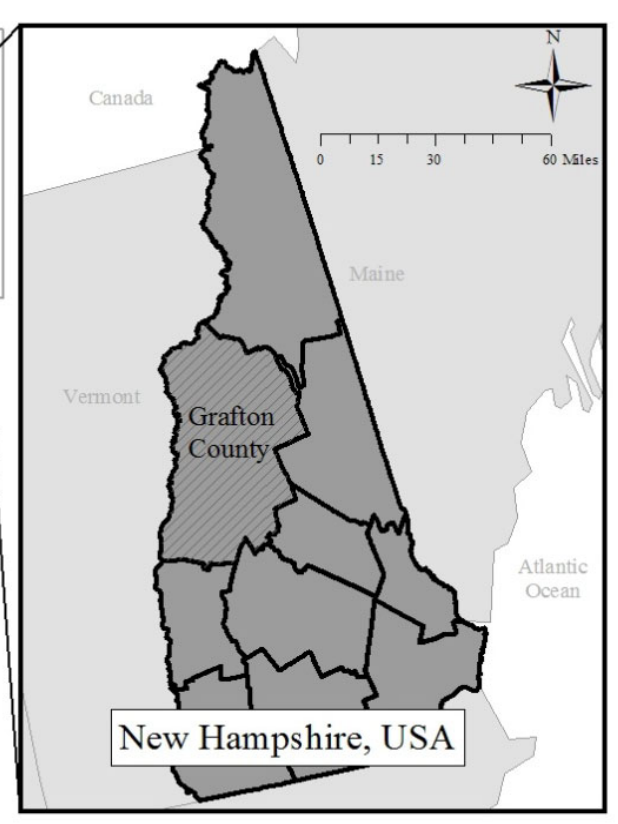

The one-on-one semistructured interviews (Morgan \& Krueger, 1998) with this group of respondents lasted between 60 and 90 minutes and took place in an office setting, community center, or over the phone (when in-person meetings were difficult to arrange). All interviews were recorded, transcribed, and coded. Participant observation (Flowerdew \& Martin, 1997) was conducted at a Plymouth-area soup kitchen that served weekly hot meals for free to attendees. Data from interviews as well as field notes were coded and analyzed using NVivo, qualitative analysis software ( QSR International, 2010). After data was cleaned, data was examined as a whole to gain a general sense of overall meaning and depth. Open coding was undertaken, where material was organized into groups or segments of related information (Rossman \& Rallis, 1998). We developed a qualitative codebook for efficient and consistent code assignment. Codes were examined, as well as the overall corpus of information. We identified underlying themes based primarily on respondent narratives. Over time, themes and trends emerged. Overlaps and differences between themes were identified, thus allowing their properties to be refined, ultimately resulting in progressively clear theme categories. Following theme assessment, 
Table 1. Sample Question Template Used To Interview Respondents

\begin{tabular}{|c|c|}
\hline \multicolumn{2}{|c|}{ Question Focus } \\
\hline Food access & Local food \\
\hline - How do you define inadequate food access? & - How do you define local foods? \\
\hline $\begin{array}{l}\text { - Do you believe inhabitants of (state/county/ } \\
\text { town) experience inadequate food access? }\end{array}$ & $\begin{array}{l}\text { - Do you believe local foods are increasing in } \\
\text { popularity among residents of (county/town)? }\end{array}$ \\
\hline - What would you say are the top three reasons & Why or why not? \\
\hline $\begin{array}{l}\text { for people not having adequate access to } \\
\text { healthy foods? }\end{array}$ & $\begin{array}{l}\text { - Do you think consumption of local products } \\
\text { depends upon income level? Nutritional }\end{array}$ \\
\hline - What would you say are the unique food & knowledge? Location? Cultural values? \\
\hline access barriers faced by rural residents? & - Do you think local foods are equally \\
\hline $\begin{array}{l}\text { - In coping with inadequate food access, which } \\
\text { group of people do you think is more likely to }\end{array}$ & $\begin{array}{l}\text { accessible by all people residing in } \\
\text { (county/town)? Why or why not? }\end{array}$ \\
\hline use their social network more? & - Do you think local foods are healthier than \\
\hline a. Lower-vs. middle-and upper-income & nonlocal foods? \\
\hline populations & - What do you see as the most common \\
\hline $\begin{array}{l}\text { - Do you think local foods make healthy eating } \\
\text { options more available to the general } \\
\text { population? }\end{array}$ & $\begin{array}{l}\text { foods? (CSA, farmers' market, grocery store, } \\
\text { informal network with relatives and/or } \\
\text { friends) }\end{array}$ \\
\hline $\begin{array}{l}\text { Do you think inhabitants of New Hampshire } \\
\text { fair better or worse when it comes to food } \\
\text { access compared to the rest of the }\end{array}$ & $\begin{array}{l}\text { - Do you think participation in local food } \\
\text { activities, such as farmers' markets and CSAs, } \\
\text { is increasing, decreasing, or stable? }\end{array}$ \\
\hline northeast? To the rest of the U.S.? & - Do you think local products are an important \\
\hline For those who experience inadequate food & part of the general public's diet? \\
\hline $\begin{array}{l}\text { access, do you see their situation improving in } \\
\text { the next five years? }\end{array}$ & $\begin{array}{l}\text { - Do you think consumption of local products } \\
\text { depends upon cultural values? }\end{array}$ \\
\hline & $\begin{array}{l}\text { - Who do you think has a greater appreciation } \\
\text { of local foods? }\end{array}$ \\
\hline & $\begin{array}{l}\text { a. Lower-vs. middle-and upper-income } \\
\text { populations } \\
\text { b. Urban vs. rural populations }\end{array}$ \\
\hline & $\begin{array}{l}\text { - In general, who do you think consumes more } \\
\text { local products: people who live in cities, or } \\
\text { people who live in "the country"/rural areas? }\end{array}$ \\
\hline
\end{tabular}

and those of other researchers, indicating that our data may be indicative of trends elsewhere, especially in rural areas of the northeastern United States where similar demographic and cultural traits exist. In this way, we also see potential in terms of research trajectories and policy reforms for those looking to build capacity between the PEFS and the local food system.

\section{Reliance upon Volunteers}

In relation to the existing criticisms that the PEFS is actually serving a long-term and

interconnections and relations between themes were identified through concept mapping and triangulation (Fielding \& Fielding, 1986). The authors conducted all interviews and observation, processed all data, and conducted all analysis. Institutional Review Board approval was obtained and all standard research protocols used.

\section{Findings from Grafton County}

Some of the data emerging out of the Grafton County case echoes previous observations about the PEFS. The preliminary data we present in this article is the product of field work, policy evaluation, and literature review. We do not claim that these findings are externally generalizable, although we do see similarities between our observations sustained need and not a short-term or emergency one, many food pantry workers indicated that longterm usage by clients was common. For instance, one pantry worker explained that "most of the people that come in here are...I don't know if I would say chronic, but regulars" (0607). ${ }^{3}$ In these pantries, representatives talked about getting to know clients over the course of months and years of use; some clients stay and talk with pantry workers for emotional support during food pickups. This long-term usage has been critiqued and connected to the fact that the PEFS is so heavily reliant upon volunteer labor that resultantly there

\footnotetext{
${ }^{3}$ The four-digit number indicates interview location and respondent IDs.
} 
are opportunities for inconsistencies to develop (Lipsky, 1985; Molnar et al., 2001). Ad hoc administration of private emergency food distribution has consequences, such as inconsistent eligibility requirements and quality control (Daponte \& Bade, 2006). In Grafton County pantries, eligibility was determined through a combination of criteria, such as pantry worker's personal judgment and preset income criteria. In one large pantry, more refined conditions were followed by staff and volunteers. In this pantry, if it was a client's first visit, then they were allowed to get food no matter what. However, in order to get food on subsequent visits they would need to bring proof of income (their income had to be below a certain amount based on number of household members). The director of this pantry explained, "the only time I turn them away is if they're using the other food pantries....Most of the time they trip themselves up" (0505). When asked about the consequences of using more than one pantry, the same respondent said, "I turn them off for a whole year....To me, that's stealing food because that's government food involved in both places" (0505). This was not a set rule or policy of the pantry, but a guideline created by the director. Another worker explained that clients needed to fill out a TEFAP form (which determines eligibility under the rubrics of "Program" (already receiving a form of public assistance) and "Income" (one-person weekly income at or below USD370)), but that "it [the form] doesn't turn anybody away" (1215). The downside of a more subjective, informal system is that pantries can be run in a potentially inequitable manner (Daponte \& Bade, 2006). In addition, a client who offended a staff member or volunteer in the past will not be safeguarded against as they would be in a government-run system. A pantry director from a small church-run pantry was asked about assistance eligibility and replied that:

We don't ask a lot of questions... We don't take any financial information and you don't need to qualify. I just tell people, "if you need it, you can use it."...You can tell by looking at them, you know? The car they drive, their clothes, you could tell they're not living high off the hog, so to speak. (0607, emphasis added)
In New Hampshire, 92 percent of food pantries and 100 percent of soup kitchens use volunteer labor, while 64 percent of pantries and 46 percent of soup kitchens rely completely on volunteer labor (Feeding America, 2010b). Volunteers partnered with pantry staff to perform tasks. Food has to be inspected, sorted, organized, and in some cases cleaned before it is handed out; how these tasks are carried out varies by pantry. In all pantries visited as part of this research, clients waited in line with other recipients (visible to each other) where nonpantry visitors to the agency could see them openly. In one venue, while pantry clients picked their food from a closet in a church, people working to set up a church dinner worked in the same room; these individuals and the pantry clients were visible openly to each other. These patterns show that by engaging in this private form of food assistance, clients give up any right to confidentiality they may be afforded through other forms of assistance, such as those offered by federal or state forms of food assistance.

Another consequence of reliance on volunteer labor is that food standards are frequently disregarded. A set of pantry workers explained how they went to great lengths to utilize some squash donated from a nearby farm:

We discovered a couple years ago that he can't keep it here [the pantry] because it will spoil... and then I said I'll take it, I got a place.... So now I've got squashes and I keep an eye on them to make sure they aren't spoiling.... So I have a room downstairs [in her house] that has no windows and it's about 55 [degrees]. And I put them down in the basement and then I bring them up into the garage and they're stored in the garage where it doesn't freeze. (0506)

Pantry and food bank workers often clean and repackage food that is inconveniently packaged (e.g., in bulk) or has been broken open. ${ }^{4}$ These

\footnotetext{
${ }^{4}$ A leading antihunger effort in New Hampshire is the New Hampshire Food Bank (NHFB), the state's only food bank and a member of Feeding America. In 2008 the NHFB

"distributed over 5 million pounds of donated, surplus food to
} 
findings not only underscore the role of volunteer subjectivity, but they more broadly illustrate the negative externalities that can emerge in this unregulated system.

\section{Food Preferences: "Change Your Taste Buds"}

Depending on the agency, food preferences of clients may have minimal influence over foods received. Nutritional, cultural, or taste preferences can be disregarded, while pantry staff beliefs dictate allotments. A volunteer who worked at a pantry and soup kitchen and also served on the board of the pantry said, "the younger ones [clients] are very, very fussy, they are turning their nose up at different things.... Whereas if you're hungry, you accept and you learn to do it and change your taste buds" (0506, emphasis added). In the same interview as the one quoted above, this respondent reflected that "we're a spoiled society" and "there's a lot of honest need, but I think there's also those that are needy who don't help themselves" (0506). This respondent seems to believe that clients should be thankful for whatever they get, no matter what, since it is better than nothing. This is similar in a sense to how pantries are pressured into being thankful for all donations out of fear that refusal of items would jeopardize future giving (for an example, see Winne (2005)).

Believing that clients should "change their taste buds" to accommodate the food available at the pantry food represents a misalignment between clients' nutritional well-being and the pantry objective of efficiently distributing all donated food. This respondent held a position of power within the pantry and was able to make managerial-level decisions. Following through on her sentiments means that clients should adjust their personal taste preferences to whatever donors decide to donate. Client preferences are interpreted by pantry staff in

386 food pantries, soup kitchens, shelters, day care centers and senior citizen homes" (N.H. Food Bank, 2010). In total N.H. has 441 agencies registered with NHFB that provide food to 71,417 people annually. Grafton County has 18 food pantries, which "distribute non-prepared foods and other grocery products to needy clients, who then prepare and use these items where they live" and where " $[\mathrm{F}]$ ood is distributed on a short-term or emergency basis until clients are able to meet their food needs" (N.H. Food Bank, 2010). a number of ways; consider the experience of this employee who worked at a smaller pantry in a northern part of the county:

I had a guy call me today and wanted me to take his name off the list here and I said “OK." I said "did you get a job?" I know he was looking for a job, "no, but I can't eat that crap." He said, "I like to eat organic now, natural food." He said, "I can't eat this stuff, processed kind of food." He said, "not that I don't appreciate what you're doing for me, but I just can't eat that kind of food." I said, "well, get a job" or that's what I felt like saying.... Do you know how much that stuff costs? We're not the end all, we're just supplemental here, we can't provide food for you for the week. I mean its just not going to happen. (0607)

This employee appeared offended by this man's decision to stop accessing the pantry. By participating in the PEFS, these individuals relinquish rights and standards they may have in the public retail sphere (i.e., where federally and state enforced food safety regulations are upheld) and as a result are forced to gamble on the whims of the largely unregulated PEFS. This removal of food rights places food-insecure individuals in an even more food-precarious state, disempowering them beyond that which is accomplished through retail markets.

One pantry worker explained that when individuals donate food, "lots of times it's ramen noodles because you can donate a lot at a low price" (0709). Food-pantry representatives working with a food-insecure population indicated that this group prefers quick and easy meals in the form of processed products, and also lacks adequate knowledge about nutrition and cooking to make informed food selections. Simultaneously, those accessing pantries revealed that food was a flexible budget item that could be adjusted according to the demands of other expenses. This often leads to trading down of items purchased - from more expensive, healthy items to cheaper, less healthy items. 
Food pantry representatives commented on how clients, especially young ones, prefer quick and easy products because "it's so much easier to open a can...things that are quick" (0506). Another pantry worker commented that "it's great when they say they cook....It just makes it so much easier to give them bags of nutritional food, but sometimes they'll just want the canned spaghetti, macaroni and cheese, hot dogs... foods that are easy to prepare for families," which she acknowledged as "a problem" (0709). Efforts to reform these eating habits were evident; one pantry worker reflected on how they had tried to switch from white to wheat bread, but found that "the wheat bread was not a hit" (1215). A nutrition professional working at a nonprofit described an attempt to change her clients' eating habits. She explained that her efforts were aimed at making people more nutritionally informed by showing them that eating healthier can be more affordable:

We will do a comparison and we will make a meal with Hamburger Helper and we'll make basically homemade Hamburger Helper.... I'll do a comparison of what Hamburger Helper costs and what it costs to make it from scratch. It's always of course cheaper to make it from scratch and then we do a taste test. And unfortunately many of the people have grown up with Hamburger Helper so that's what they like.... They don't see the difference; how salty and awful it tastes....We'll do a whole cost analysis and they'll see it's about 59 cents a serving if you make it from scratch compared to about 79 cents a serving for Hamburger Helper. (1013)

Another pantry worker explained:

I think it's pricing, but then we have people, you know I believe it comes from how you grew up. You know, a lot of people shop the way their moms or dads shopped. And some people were just brought up on frozen boxed food and not cooked homemade meals and so that's all they know how to purchase. (0303)
This may explain why pantries experience a demand for these easy-to-cook processed foods. While some pantries might push more nutritional options, others send contradictory nutritional messages. Not far from where the abovementioned nutritional professional worked, another pantry worker at the same agency remarked that "the stuff that's easy for us to get is pasta, canned stuff, pasta mixes, and it's not highly nutritional.... Tuna or some kind of a tinned meat, you know, with a Tuna Helper, that's the kind of stuff we get here because we don't have any way to give them fresh meat" (0607). The food being donated is free for the pantry and free for the clients, made possible through private, often corporate donors. This represents a seemingly collaborative alignment between the need to dispose of unwanted food on behalf of corporate donors and the need for foodinsecure clients to consume food, yet this arrangement is rooted in a short-term outlook and power imbalance where corporate food entities are able to dump unwanted food for free upon a foodinsecure population, thereby realizing short-term profit gains (for the business) at the cost of longterm health of food-insecure individuals and its effect on governments.

\section{Assessing Collaborative Potential}

The rural PEFS appears to be similar to the urban PEFS in a number of ways. It is heavily reliant upon volunteer labor and it serves a significant proportion of the population, often on a regular basis. In the rural context there is a dispersed population. While centralized population centers like cities provide efficient and short-distance transportation networks, rural networks are decentralized with people living in remote areas, often requiring automobile access. This has a few practical consequences. A dispersed population also means that community food-growing opportunities like neighborhood gardens are more difficult to organize and implement when compared to a city where a group of neighbors can have a small vegetable plot within walking distance. Contrastingly, in many rural places the transportation cost of getting to a community space where a garden may be located represents another financial and logistical barrier. Cities are also places where 
people can more easily congregate to meet and organize reactive and proactive responses to inadequate food access (for example, to grow a neighborhood garden in response to being located in a "food desert"). In urban areas for instance, these have manifested in food justice efforts. In rural areas, the PEFS is the chief response to hunger and food insecurity (in addition to federal and state mandated programs).

However, the rural PEFS operates on a smaller scale with fewer numbers of people accessing it and a high degree of malleability. As described earlier in this essay, this informality has been criticized; however, this ability to adapt means that individuals who operate PEFS entities (like food pantries) can take advantage of opportunities without having to obtain approval from higher levels of bureaucracy. In addition, the rural PEFS is often located where the land, soil, water, and air resource base for growing food is abundant. In contrast to the literature that supports the claims that low-income populations prefer processed foods (Drewnowski \& Specter, 2004), data from the Grafton County case shows that in the pantries that were able to obtain small amounts of fresh, perishable foods (meats and fresh fruits and vegetables), these quickly became the most popular items. As one pantry worker explained:

Most people know that an apple is healthier than a hot dog, but those [hot dogs] are way cheaper, you know, not that they're the same in any way.... Here [at the food pantry] they would go for the things that they don't normally get their hands on, which is why those dairy products go fast and those veggies go fast. But I think in general when they are shopping they go for the cheapest, easiest thing to get through to the next week. (1215)

In another study of Grafton County, a food pantry employee described how a local hunter donated moose meat:

Interviewer: What are the most popular items that you have here in the pantry?

Respondent 1: Meat. It's the most expensive...
Respondent 2: Oh, was it last year we got the moose meat? We got 500 pounds [230 kg]. And we're thinking, what are we gonna do with all this moose meat? And it flew out of here. I mean, people were calling us and asking us for some. (McEntee, 2011b, p. 251)

A key question emerging from this research is, "how do we harness the assets of both the PEFS and local food system to better serve the needs of food-insecure populations?" There is a demand for locally produced produce and meat on behalf of food-insecure individuals (as others have shown; see Hinrichs and Kremer (2002)). The desires of low-income consumers to eat fresh meat and produce (which often is locally produced) as well as to participate in some local food production activities (whether it be hunting or growing vegetables) have been overlooked by researchers. People accessing the PEFS in rural areas are accessing pantries, but also growing their food because it is an affordable way to obtain high-quality food they may otherwise not be able to afford (McEntee, 2011b).

Based on the information provided in this article, potential synergies between the PEFS and the local food system in the rural context exist. Specifically, a traditional localism engages "participants through non-capitalist, decommodified means that are affordable and accessible" where "food is grown/raised/hunted, not with the intention to gain profit, but to obtain fresh and affordable food" (McEntee, 2011, pp. 254-255). Traditional localism allows for local food to become an asset for many food-insecure and poor communities that are focusing on the need to address inadequate food access. How could the rural PEFS source more food locally, thereby strengthening the local economy? How could private emergency food entities like food pantries and local food advocates promote food-growing, food-raising, and hunting activities as a means to increase grassroots, local, and affordable access to food? Like many places throughout the U.S., Grafton County is home to small-scale local agriculture operations supported by an enthusiastic public and sympathetic state.

Simultaneously, there is the presence of food insecurity and a PEFS seeking to remediate this 
persistent problem. The actual structure of the PEFS could be thoroughly assessed (beyond the borders of Grafton County). If warranted, this system could be redesigned to prioritize privacy and formalize procedures in terms of ensuring that client food choices are respected. A crucial next step in reforming this system to benefit lowincome and minority clients is to emphasize the ability to grow, raise, and hunt food for their own needs ${ }^{5}$ through the traditional local concept. This would represent a transformation in which these activities could not only be supported by the PEFS, but also draw upon the social capital of communities in the form of memories and practices of rural people from the near past, all while reducing reliance upon corporate waste. If traditional local efforts were organized on a cooperative model, based on community need and not only the needs of individuals, it would benefit all those participating, drawing on collective community resources, such as food-growing knowledges and skills, access to land, and tools, thereby enhancing the range of rural livelihood strategies. In this sense, these activities are receptive to racial and economic diversity as well as alliance-formation across social groups and movements, all of which are characteristic of the food sovereignty movement (HoltGiménez \& Wang, 2011).

In moving forward additional research is needed. While our findings highlight potential shortcomings, there is a lack of data exploring the rural PEFS experience. Specifically, from the demand side, we need more data about the users of this system, specifically in regard to their satisfaction with food being given to them. Are they happy with it? Do they want something different that is not available? Do they lack the ability to cook certain foods being handed out by the pantry? Feeding America's Hunger in America survey asks about client satisfaction; in its 2010 report, only 62.7 percent of surveyed clients were "very satisfied" with the overall quality of the food

\footnotetext{
${ }^{5}$ A noteworthy example of an organization that has begun to accomplish these objectives is The Stop Community Food Centre in Toronto, which was recently described by Levkoe and Wakefield (2012).
}

provided. ${ }^{6}$ Additionally, the fact that this survey is administered by the same personnel who are distributing food donations raises methodological biases. More needs to be discovered about why such a large proportion of users is not "very satisfied." From the supply side, we need to know more about food being distributed and its nutritional value. Currently, the food being donated and distributed is unregulated to a large degree, especially in rural pantries. Also on the supply side, the source of food provided to Feeding America as well as individual state food banks and food pantries needs to be inventoried with more information beyond just its weight. Knowing the quantity of specific donated products as well as the financial benefit (in terms of tax write-offs) afforded to donors would add transparency.

\section{Conclusion: Neoliberal Considerations and Future Directions}

The findings we have presented in this article are intended to reveal important policy questions about the PEFS and local food movement; we do acknowledge, however, that it also has raised some important questions. In summary, we see opportunities to move forward in enacting a food sovereignty agenda with both local and global scales in mind. First, value-added, market-based local solutions used to address the inadequacies of the current food system are immediately beneficial. However, these should not be accepted as the endall solution. Looking beyond them to determine what else can be accomplished to change the structure of the food system to shift power away from oligarchic food structures of the corporate food regime to food citizens, not only food consumers, would result in systemic change.

A key consideration in realizing any reform in the PEFS, and simultaneously challenging and transforming the unsustainable global food regime, is recognizing the neoliberal paradigm in which government and economic structures exist. Neoliberalism can be defined as a political philosophy that promotes market-based rather than state-based

\footnotetext{
${ }^{6}$ The remaining categories are: "Somewhat satisfied" (31.3 percent), "Somewhat dissatisfied" (4.8 percent), and "Very dissatisfied" (1.3 percent).
} 
solutions to social problems, while masking social problems as personal deficiencies. The PEFS is essentially acting as a vent for unwanted food in this system that also provides a financial benefit to the governing food entities (i.e., food businesses). Too often alternatives are hailed as opposing the profit-driven industrial food system simply because they are geographically localized; in reality, they may re-create the classist and racist structures that permeate the larger global system. ${ }^{7}$ The PEFS is an embedded neoliberal response to food insecurity; while public-assistance enrollment is on the rise, so is participation in the PEFS. This is a shift in responsibility in who is providing assistance to food-insecure populations from the government to the private sector. In this sense it is a market-based approach to addressing food insecurity (i.e., by dumping food on the private charity sector, market retailers cut their own waste disposal costs), and the result is continual scarcity and the establishment of a system that reinforces the idea that healthy food is a privilege, only accessible to those with adequate financial and social capital. Along these same lines, a form of food localism exists that is arguably detrimental to those without financial and social capital; these efforts have and continue to frame food access solely as an issue of personal responsibility related to economic status and nutritional knowledge (a narrative thoroughly discussed by Guthman $(2007,2008))$. This prioritizes market-based solutions to developing local food systems as well as universal forms of food education that emphasize individual health. As Alkon and Mares (2012) explain,

Neoliberalism creates subjectivities privileging not only the primacy of the market, but individual responsibility for our own wellbeing. Within U.S. food movements, this refers to an emphasis on citizen empowerment, which, while of course beneficial in many ways, reinforces the notion that individuals and community groups are responsible

\footnotetext{
${ }^{7}$ For additional discussion of the political economic transition from government to governance, such as the transfer of state functions to nonstate and quasistate entities, see Purcell (2002).
}

for addressing problems that were not of their own making. Many U.S. community food security and food justice organizations focus on developing support for local food entrepreneurs, positing such enterprises as key to the creation of a more sustainable and just food system. The belief that the market can address social problems is a key aspect of neoliberal subjectivities. (p. 349)

Though elements of both the PEFS and the local food system have arguably been folded into neoliberalization processes through market-based mechanisms, incremental steps to change these dynamics are possible. Reframing issues of food accessibility (including food insecurity, hunger, food deserts, etc.) as issues of food justice moves us beyond an absolute spatial understanding of food issues. For instance, when we only look at physical access to food, we often disregard the more important considerations of class, race, gender (see Alkon and Agyeman, 2011), and sexual orientation that define a person's present position (and over which they often have no control) and which dictate how they engage with the food system. These considerations are present in current food-justice efforts, which seek to ensure that communities have control over the food grown, sold, and consumed there. Rural food justice has been defined using the traditional localism concept:

Traditional localism in rural areas engages participants through non-capitalist, decommodified means that are affordable and accessible. Food is grown/raised/hunted, not with the intention to gain profit, but to obtain fresh and affordable food. A traditional localism disengages from the profit-driven food system and illustrates grassroots food production where people have direct control over the quality of the food they consume a principal goal of food justice. (McEntee, 2011b, pp. 254-255)

Utilizing this rural form of food justice involves more than promoting individual food acquiring techniques; it involves developing organizational and institutional strategies that improve the quality 
of food available to PEFS entities. This is currently accomplished by some, such as when pantries obtain fresh produce through farmer donations or when a food bank develops food-growing capacity. ${ }^{8}$ But these types of entities are in the minority. The next stage of realizing food justice, we posit, is to determine how a food sovereignty approach can be utilized in a global North context. Food justice predominantly operates to find solutions within a capitalist framework (and it has been criticized as such) while food sovereignty is explicitly geared toward the dismantling of this system in order to achieve food justice. Regime change and transformation requires more than recognition and control over food-growing resources; it requires alliance and partnership-building between groups to "to address ownership and redistribution over the means of production and reproduction" (HoltGiménez \& Wang, 2011, p.98). Adopted by organizations predominantly located in the global South, food sovereignty is focused on the causes of food system failures and subsequently looks toward "local and international engagement that proposes dismantling the monopoly power of corporations in the food system and redistributing land and the rights to water, seed, and food producing sources" (Holt-Giménez, 2011, p. 324). There is an opportunity for people in the global North not only to learn from the global South food sovereignty movements, but to form connections and alliances between North and South iterations of these movements. ${ }^{9}$ As discussed above, the dominant food movement narrative is in sync with the economic and development goals of government (e.g., state-sanctioned buy-local campaigns) as well as marketing prerogatives of global food corporations (e.g., "local" being used as marketing label). Build-

\footnotetext{
${ }^{8}$ An example of this type of effort is that of the Vermont Food Bank, which purchased a farm in 2008 in order to supply the food bank with fresh, high-quality produce as well as to sell the produce.

9 The U.S. Food Sovereignty Alliance has recognized the importance of building these coalitions: "As a US-based alliance of food justice, anti-hunger, labor, environmental, faith-based, and food producer groups, we uphold the right to food as a basic human right and work to connect our local and national struggles to the international movement for food sovereignty" (US Food Sovereignty Alliance, n.d., para. 1).
}

ing a social movement powerful enough to place meaningful political pressure upon government to support a food system that prioritizes human wellbeing, not profit, is an immediate challenge.

Incremental solutions are necessary in order to improve the lives of people now. However, these local solutions, such as innovative farm-to-school programming and other viable models between the local food environment and the PEFS that we have discussed in this article, would be more effective at affecting long-term systemic change if they were coupled with collective approaches to acknowledge and limit the power of the corporate food regime to prevent injustice, while also holding the state accountable for its responsibility to citizens, which it has successfully "relegated to voluntary and/or market-based mechanisms" (Alkon and Mares, 2012, p. 348). Food sovereignty offers more than an oppositional view of neoliberalism, however. The food sovereignty movement advances a model of food citizenship that asserts food as a nutritional and cultural right and the importance of democratic on-the-ground control over one's food. These qualities resonate with food-insecure and disenfranchised communities, urban and rural, in both the global North and South.

\section{References}

Akobundu, U.O., Cohen, N. L., Laus, M. J., Schulte, M. J., \& Soussloff, M. N. (2004). Vitamins A and C, calcium, fruit, and dairy products are limited in food pantries. Journal of the American Dietetic Association, 104(5), 811-813. http://dx.doi.org/10.1016/i.jada.2004.03.009

Alexander, D. (2003, 25 May). Bigger portions for food banks. Chicago Tribune. Retrieved from http://www.chicagotribune.com

Alkon, A. H., \& Agyeman, J. (Eds.) (2011). Cultivating Food Justice. Cambridge, Massachusetts: MIT Press.

Alkon, A. H., \& Mares, T. M. (2012). Food sovereignty in US food movements: Radical visions and neoliberal constraints. Agriculture and Human Values, 29(3), 347-359. http://dx.doi.org/10.1007/s10460012-9356-Z

Alkon, A. H., \& Norgaard, K. M. (2009). Breaking the food chains: An investigation of food justice activism. Sociological Inquiry, 79(3), 289-305. http://dx.doi.org/10.1111/j.1475682X.2009.00291.x 
Allen, P., FitzSimmons, M., Goodman, M., and Warner, K. (2003). Shifting plates in the agrifood landscape: the tectonics of alternative agrifood initiatives in California. Journal of Rural Studies, 19(1), 61-75. http://dx.doi.org/10.1016/S0743-0167(02)00047-5

Associated Press. (2010, 25 March). Con Agra Foods $3 Q$ profit rises, maintains outlook. Associated Press. New York. Retrieved from http://www.boston.com/ business/articles/2010/03/25/conagra foods 3 q profit rises maintains outlook/

Beggs, J. J. (2006). Coping with food vulnerability: The role of social networks in the lives of Missouri food pantry clients. Unpublished graduate thesis). University of Missouri, Columbia, Missouri.

Bhattarai, G. R., Duffy, P. A., \& Raymond, J. (2005). Use of food pantries and food stamps in lowincome households in the United States. The Journal of Consumer Affairs, 39(2), 276-298. http://dx.doi.org/10.1111/j.17456606.2005.00015.x

ConAgra. (2009). ConAgra Foods' First Corporate Responsibility Report Now Available. Retrieved 1 January 2011 from http://media.conagrafoods. $\mathrm{com} /$ phoenix.zhtml? $\mathrm{c}=202310 \& \mathrm{p}=$ irolnewsArticle\&ID=1269902\&highlight=

Daponte, B. O., \& Bade, S. (2006). How the private food assistance network evolved: Interactions between public and private responses to hunger, Nonprofit and Voluntary Sector Quarterly, 35(4), 668690.

Daponte, B. O., Lewis, G. H., Sanders, S., \& Taylor, L. (1998). Food pantry use among low-income households in Allegheny County, Pennsylvania. Journal of Nutrition Education, 30(1), 50-57. http://dx.doi.org/10.1016/S0022-3182(98)70275-4

Drewnowski, A., \& Specter, S. E. (2004). Poverty and obesity: The role of energy density and energy costs. The American Journal of Clinical Nutrition, 79(1), 6-16.

Feeding America. (2010a). Hunger in America 2010 national report. Chicago: Feeding America and Mathematica Policy Research, Inc. Retrieved from http://feedingamerica.issuelab.org/resource/ hunger in america 2010 national report

Feeding America. (2010b.) Hunger in America 2010: Local report prepared for the New Hampshire Food Bank. Chicago: Feeding America. Retrieved from http://www.nhfoodbank.org/about-hunger/ hunger-study.html

Feeding America. (2012a). Food, Grocery Donations and Food Drives. Retrieved from http:// feedingamerica.org/ways-to-give/foodgrocery-food-drives.aspx

Feeding America. (2012b). Leadership Partners. Retrieved from http://feedingamerica.org/howwe-fight-hunger/our-partners/leadershippartners.aspx

Feeding America. (2012c). Programs \& Services. Retrieved from http://feedingamerica.org/howwe-fight-hunger/programs-and-services.aspx

Feenstra, G. W. (1997). Local food systems and sustainable communities. American Journal of Alternative Agriculture, 12(1), 28-36. http://dx.doi.org/10.1017/S0889189300007165

Fielding, N., \& Fielding, J. (1986). Linking data. Beverly Hills, California: Sage.

Flowerdew, R., \& Martin, D. (1997). Methods in buman geography: A guide for students doing a research project. London: Sage.

Food Lion. (2010). Food Lion community connections.

Retrieved 1 January 2011 from http://www.foodlion.com/Charities/FeedingAmerica

Furst, T., Connors, M., \& Bisogni, C. (1996). Food choice: A conceptual model of the process. Appetite, 26(3), 247-266. http://dx.doi.org/10.1006/appe.1996.0019

Gottlieb, R., \& Joshi, A. (2010). Food justice. Cambridge, Massachusetts: MIT Press.

Guthman, J. (2007). The Polanyian way? Voluntary food labels as neoliberal governance. Antipode, 39(3), 456-478. http://dx.doi.org/10.1111/j.14678330.2007.00535.x

Guthman, J. (2008). "If they only knew": Color blindness and universalism in California alternative food institutions. The Professional Geographer, 60(3), 387-397. http://dx.doi.org/10.1080/00330120802013679

Hilton, K. (1993). Close down the food banks. Canadian Dimension, 27(4), 22-23.

Hinrichs, C. C., \& Kremer, K. S. (2002). Social inclusion in a Midwest local food system project. Journal of Poverty, 6(1), 65-90. http://dx.doi.org/10.1300/J134v06n01 04 
Holt-Giménez, E. (2011). Food security, food justice, or food sovereignty? Crises, food movements, and regime change. In A. H. Alkon \& J. Agyeman (Eds.), Cultivating food justice (pp. 309-330). Cambridge, Massachusetts: MIT Press.

Holt-Giménez, E., \& Wang, Y. (2011). Reform or transformation? The pivotal role of food justice in the U.S. food movement. Race/Ethnicity: Multidisciplinary Global Contexts, 5(1), 83-102. http://dx.doi.org/10.2979/racethmulglocon.5.1.83

Irwin, J. D., Ng, V. K., Rush, T. J., Nguyen, C., \& He, M. (2007). Can food banks sustain nutrient requirements? A case study in Southwestern Ontario. Canadian Journal of Public Health, 98(1), 1720.

Kloppenburg, Jr., J., Lezberg, S., De Master, K., Stevenson, G. W., \& Hendrickson, J. (2000). Tasting food, tasting sustainability: Defining the attributes of an alternative food system with competent, ordinary people. Human Organization, 59(2), 177-186.

La Via Campesina. (2011). Defending food sovereignty.

Retrieved 9 November 2012 from

http://viacampesina.org/en/index.php/ organisation-mainmenu-44

Levkoe, C. (2006). Learning democracy through food justice movements. Agriculture and Human Values, 23(1), 89-98. http://dx.doi.org/10.1007/s10460005-5871-5

Levkoe, C. Z., \& Wakefield, S. (2012). The Community Food Centre: Creating space for a just, sustainable, and healthy food system. Journal of Agriculture, Food Systems, and Community Development, 2(10), 249-268.

Light, R. J., Singer, J., \& Willett, J. (1990). By design: Conducting research on higher education. Cambridge, Massachusetts: Harvard University Press.

Lipsky, M. (1985). Prepared statement before the Subcommittee on Domestic Marketing, Consumer Relations, and Nutrition of the Committee on Agriculture of the U.S. House of Representatives, 99th Cong., 2nd session.

McEntee, J. C. (2010). Contemporary and traditional localism: A conceptualisation of rural local food. Local Environment, 15(9), 785-803. http://dx.doi.org/10.1080/13549839.2010.509390

McEntee, J.C. (2011a). Shifting rural food geographies and the spatial dialectics of just sustainability. (Doctoral dissertatiaon). Cardiff, UK: Cardiff
University. http://library.cardiff.ac.uk/vwebv/ holdingsInfo?bibId $=945965$

McEntee, J. C. (2011b). Realizing rural food justice: Divergent locals in the northeastern United States. In A. H. Alkon and J. Agyeman (Eds.), Cultivating food justice (pp. 239-260). Cambridge, Massachusetts: MIT Press.

Molnar, J. J., Duffy, P. A., Claxton, L. \& Conner, B. (2001). Private food assistance in a small metropolitan area: Urban resources and rural needs. Journal of Sociology and Social Welfare, 28(3), 187-209.

Monsivais, P., \& Drewnowski, A. (2007). The rising cost of low-energy-density foods. Journal of the American Dietetic Association, 107(12), 2071-2076. http://dx.doi.org/10.1016/j.jada.2007.09.009

Morgan, D. L., \& Krueger, R. A. (1998). The focus group kit. Thousand Oaks, California: Sage Publications.

Morgan, K., Marsden, T., \& Murdoch, J. (2006). Worlds of food. Oxford: Oxford University Press.

Morton, L. W., \& Blanchard, T. C. (2007). Starved for access: Life in rural America's food deserts. Rural Realities, 1(4), 1-10.

Mosley, J., \& Tiehen, L. (2004). The food safety net after welfare reform: Use of private and public food assistance in the Kansas City metropolitan area. Social Service Review, 78(2), 267-283. http://dx.doi.org/10.1086/382769

New Hampshire Food Bank [N.H. Food Bank]. (2010). New Hampshire Food Bank. Retrieved 1 April 2010 from http://www.nhfoodbank.org/index.php? option $=$ com content $\&$ view $=$ frontpage \&Itemid $=1$

Nord, M., Andrews, M., \& Carlson, S. (2008). Measuring food security in the United States: Household food security in the United States, 2007 (Food Assistance and Nutrition Research Report No. 66). Washington, D.C.: United States Department of Agriculture.

QSR International. (2010). NVivo [qualitative research software]. Cambridge, Massachusetts: QSR International.

Procter \& Gamble, 2010. P\&G and Feeding America: Fighting hunger. Retrieved 2 April 2010 from http://www.pg.com/en_US/sustainability/ social responsibility/feeding america.shtml

Poppendieck, J. (1998). Sweet charity? Emergency food and the end of entitlement. New York: Penguin. 
Purcell, M. (2002). Excavating Lefebvre: The right to the city and its urban politics of the inhabitant. Geoforum, 58(2-3), 99-108.

Rock, M., McIntyre, L., \& Rondeau, K. (2009). Discomforting comfort foods: Stirring the pot on Kraft Dinner and social inequality in Canada. Agriculture and Human Values, 26(3), 167-176. http://dx.doi.org/10.1007/s10460-008-9153-x

Rossman, G., \& Rallis, S. F. (1998). Learning in the field: An introduction to qualitative research. Thousand Oaks, California: Sage.

Sharkey, J. R. (2009). Measuring potential access to food stores and food-service places in rural areas in the U.S. American Journal of Preventative Medicine, 36(4S), S151-S155.

Sims, R. (2009). Food, place and authenticity: Local food and the sustainable tourism experience. Journal of Sustainable Tourism, 17(3), 321-336. http://dx.doi.org/10.1080/09669580802359293

Stewart, H., Blisard, N., \& Jolliffe, D. (2006). Let's eat out: Americans weigh taste, convenience, and nutrition (Economic Information Bulletin No. EIB-19). Washington, D.C.: United State Department of Agriculture.

Tarasuk, V., \& Eakin, J. M. (2005). Food assistance through "surplus" food: Insights from an ethnographic study of food bank work. Agriculture and Human Values, 22(2), 177-186. http://dx.doi.org/10.1007/s10460-004-8277-x

Tiehen, L. (2002). Issues in food assistance: Private provision of food aid: The emergency food Assistance system (Food Assistance and Nutrition Research Report No. 26-5). Washington, D.C.: United States Department of Agriculture.

U.S. Census Bureau. (2008). Census 2000, American FactFinder. Retrieved from http:// factfinder. census.gov/home/saff/main.html? lang=en

U.S. Department of Agriculture. (2012). United States Department of Agriculture, Census of Agriculture. Available from: http://www.agcensus.usda.gov/ Publications/2007/index.php

U.S. Department of Agriculture, Agricultural Marketing Service [USDA AMS]. (2012). United States Department of Agriculture, Agricultural Marketing Service. Retrieved from http://search.ams.usda.gov/farmersmarkets/
U.S. Department of Agriculture, Food and Nutrition Service [USDA FNS]. (2010). United States Department of Agriculture, Food and Nutrition Service. The Emergency Food Assistance Program. Retrieved from http://www.fns.usda.gov/fdd/programs/tefap/

USDA FNS. (2012a). United States Department of Agriculture, Food and Nutrition Service. SNAP Retailer Locator. Retrieved from http://www.snapretailerlocator.com/

USDA FNS. (2012b). Program data. Retrieved from http://www.fns.usda.gov/pd/cnpmain.htm/

U.S. Food Sovereignty Alliance. (n.d.). About the Alliance. Retrieved 1 June 2012 from http://www.usfoodsovereigntyalliance.org/about

Verpy, H., Smith, C., \& Reicks, M. (2003). Attitudes and behaviors of food donors and perceived needs and wants of food shelf clients. Journal of Nutrition Education and Behavior, 35(1), 6-15. http://dx.doi.org/10.1016/S1499-4046(06)60321-7

Walmart. (2010). Walmart Corporate: Feeding America. Retrieved 1 March 2010 from http://walmartstores.com/CommunityGiving/ 8803.aspx

Warshawsky, D. N. (2010). New power relations served here: The growth of food banking in Chicago. Geoforum, 41(5), 763-775. http://dx.doi.org/10.1016/j.geoforum.2010.04.008

Wekerle, G. R. (2004). Food justice movements: Policy, planning, and networks. Journal of Planning Education and Research, 23(4), 378-386. http://dx.doi.org/10.1177/0739456X04264886

Welsh, J., \& MacRae, R. (1998). Food citizenship and community food security. Canadian Journal of Development Studies, 19, 237-55. http://dx.doi.org/10.1080/02255189.1998.9669786

Winne, M. (2005). Waste not, want not? Agriculture and Human Values, 22(2), 203-205. http://dx.doi.org/10.1007/s10460-004-8279-8

Winter, M. (2003). Embeddedness, the new food economy and defensive localism. Journal of Rural Studies, 19(1), 23-32. http://dx.doi.org/10.1016/S0743-0167(02)00053-0

Wu, C., \& Eamon, M. K. (2007). Public and private sources of assistance for low-income households. Journal of Sociology \& Social Welfare, 34(4), 121-149. 